\title{
Seasonal Trends in Energy Contents of Storage Substances in Evergreen Gymnosperms Growing Under Mild Climatic Conditions in Central Europe.
}

\author{
H. Distelbarth, U. Kull and K. Jeremias $\dagger$ \\ Biologisches Institut, Universität Stuttgart, F.R.G.
}

\begin{abstract}
Summary
From the contents of the soluble sugars, starch, and total lipids measured at monthly intor: vals during the course of a year in leaves and barks of Taxus baccata, Juniperus communis, Thuja occidentalis, Picea excelsa and Sequoiadendron giganteum the energy contents of storage substances were calculated and their seasonal trends established. From Taxus and Juniperus the wood was investigated in the same manner. Furtheron, the seasonal trends in total N-contents of leaves and barks of Taxus, Juniperus and Thuja were measured. As energy storing substances the Ncompounds are not important. From the seasonal trends of the $\mathrm{N}$-contents a function of the old leaves as an important $\mathrm{N}$-storage pool for the budding may by concluded. In the one year old needles of Picea and Taxus the carbonic acid contents were measured, from an energetic point of view the acids are not important as reserve-substances.

From the seasonal trends of the energy contents in the different species a general pattern of storage in gymnosperms growing under mild climatic conditions in Central Europe was deduced (Fig. 9). Remarkably, according to this pattern the highest amounts of starch are found in the spring or early summer, the maximum contents of total lipids are reached during autumn or early winter and the highest contents of soluble sugars are found in the winter. This pattern confirms earlier assumptions regarding the functions of different storage substances.

The total energy contents decline during the growth period and reach their lowest values in the late spring and early summer. In the winter none of the species showed an extensive diminution of storage energy, but rather sometimes a rise was seen which points to a net production during the winter months. Thus, the highest energy contents in the leaves are often found in the winter. The old needles have an important function as storage sites in the evergreen gymnosperms.
\end{abstract}

\section{Introduction}

When we investigated the seasonal trends of storage substances and their energy contents in mediterranean woody plants (Diamantoglou \& Kull 1982) it proved to be necessary to compare the findings with the storage behaviour of evergreen woody plants growing under mild climatic conditions in the colline zone in Central Europe. Because the phenology changes somewhat year by year, all reserve substances of one species must be quantified during the same year's course. Evergreen plants in Central Europe are mainly gymnosperms, therefore, five of these were chosen: the native species Picea abies, Juniperus communis and Taxus baccata and the introduced species Thuja occidentalis and Sequoiadendron giganteum. These two imported species grow very well in protected locations. The investigations were limited to leaves (needles) and barks, and were completed by the examination of wood (from branches) of yew and juniper. Some of the results described here were cited previously in the discussions of the papers of Tschager et al. (1982) and of Diamantoglou \& Kull (1982). 


\section{Materials and Methods}

\section{Materials}

Leaves (needles) one year old, barks of $2-5$ year old twigs, and in some cases wood of $2-7$ year old twigs and branches were investigated.

The seasonal trends in contents of soluble sugars, starch, and total lipids in leaves and barks of Picea abies have been previously described by Jeremins (1969); from these data the energy contents could be calculated. The scaly leaves and bark of Sequoiadendron have also been investigated for seasonal trends within the same year with the exeption of the total lipids in barks (Jeremias 1969; bark: assets of K. Jeremas). We utilized Taxus baccata L., Thuja occidentalis L., and Juniperus communis $\mathrm{L}$. in our further investigations. The first two of these species contain mucilages, while Juniperus does not (Distelbarth 1982).

The plant parts of Taxus baccata and of Thuja occidentalis were harvested from about 50 year old trees obtained from the former Botanical Garden of the University Stuttgart (area presently part of the "Wilhelma"). Branches of Juniperus communis were taken from a shrub about $2 \mathrm{~m}$ high, growing in a sunny location in the former garden. Sporadic frosts occurred from November to April, however in more than one week in February the temperature every night fell below $0{ }^{\circ} \mathrm{C}$ (to a minimum of about $-5{ }^{\circ} \mathrm{C}$ ).

\section{Methods}

The branches were gathered at monthly intervals throughout the year and always at the same hour. After isolation, the different parts were frozen and lyophilized.

Quantitative estimation of storage substances

The soluble sugars were separated and quantitatively analyzed using a scanning procedure (NAGlschmid et al. 1982; Distelbarth 1982) on thin layer chromatographs using the method of JEREMIAS (1958). Wood sugar contents were determined by the anthrone-method (LoEwUs 1952).

The starch contents were measured by the method of McCready et al. (1950) using anthrone. The total lipids were quantified according to the method of BLIGH \& DYER (1959).

Investigations were made on some samples for carbonic acid contents. In the needles of Picea the organic acids were estimated quantitatively some years ago by a paper ehromatographic method (Heiteruss 1957; KULL 1968; OEchssLer 1968), in the needles of Taxus by gas-liquid chromatography using the procedure of NiERHAUs \& KinzeL (1971).

The total nitrogen contents were measured (in leaves and barks of Taxus, Juniperus and Thuja) by the method of Kjeldahl (1883) as prescribed by Beloserski \& Proskurjakow (1956). The values shown in Fig. 3 are average values from at least three measurements (standard deviation $\pm 0.03 \%$ of dry weight).

\section{Estimation of energy contents of storage substances}

From the quantitative estimations of the contents of the storage materials the energy contents were calculated as $\mathrm{kJ} / \mathrm{g}$ dry weight using the factors:

$1 \mathrm{~g}$ lipid $\triangleq 38.94 \mathrm{~kJ}$

$1 \mathrm{~g}$ carbohydrate $\triangleq 17.17 \mathrm{~kJ}$.

Quinic and shikimic acids were the most prevalent constituents of organic acids; because their sum-formula is close to that of sugars their energy contents were calculated using the same factor as for carbohydrates.

I Usually the energy content of proteins and amino acids is approximated using the same factor as for carbohydrates. We calculated hypothetic values for proteins respectively aminoacids from the total $\mathrm{N}$-contents and from these values the energy contents, which therefore are assumed to be too high.

Lipid and soluble sugar values less than $0.25 \mathrm{~kJ} / \mathrm{g}$ are not considered to be a storage energy. The fraction of total lipids includes membrane lipids and in addition vacuolar.sap always contains a certain concentration of sugars. Therefore a minimum quantity of both classes of compounds is necessary for basal cell metabolism and should not be considered storage substances. 


\section{Results}

Water content of leaves

To investigate a possible water stress (possible in Central Europe during the winter months), the water content of the needles of Taxus, Juniperus and Thuja was determined throughout the year. The crucial results are shown in Table 1.

Table 1. Water content of the needle-leaves (as $\%$ of dry weight)

\begin{tabular}{lccc}
\hline & Taxus & Juniperus & Thuja \\
\hline At the beginning of the cold season (Sept./Oct.) & 170 & 130 & 160 \\
$\begin{array}{l}\text { Lowest value; reached during late winter or early spring } \\
\text { (March/April) }\end{array}$ & 110 & 80 & 110 \\
\hline
\end{tabular}
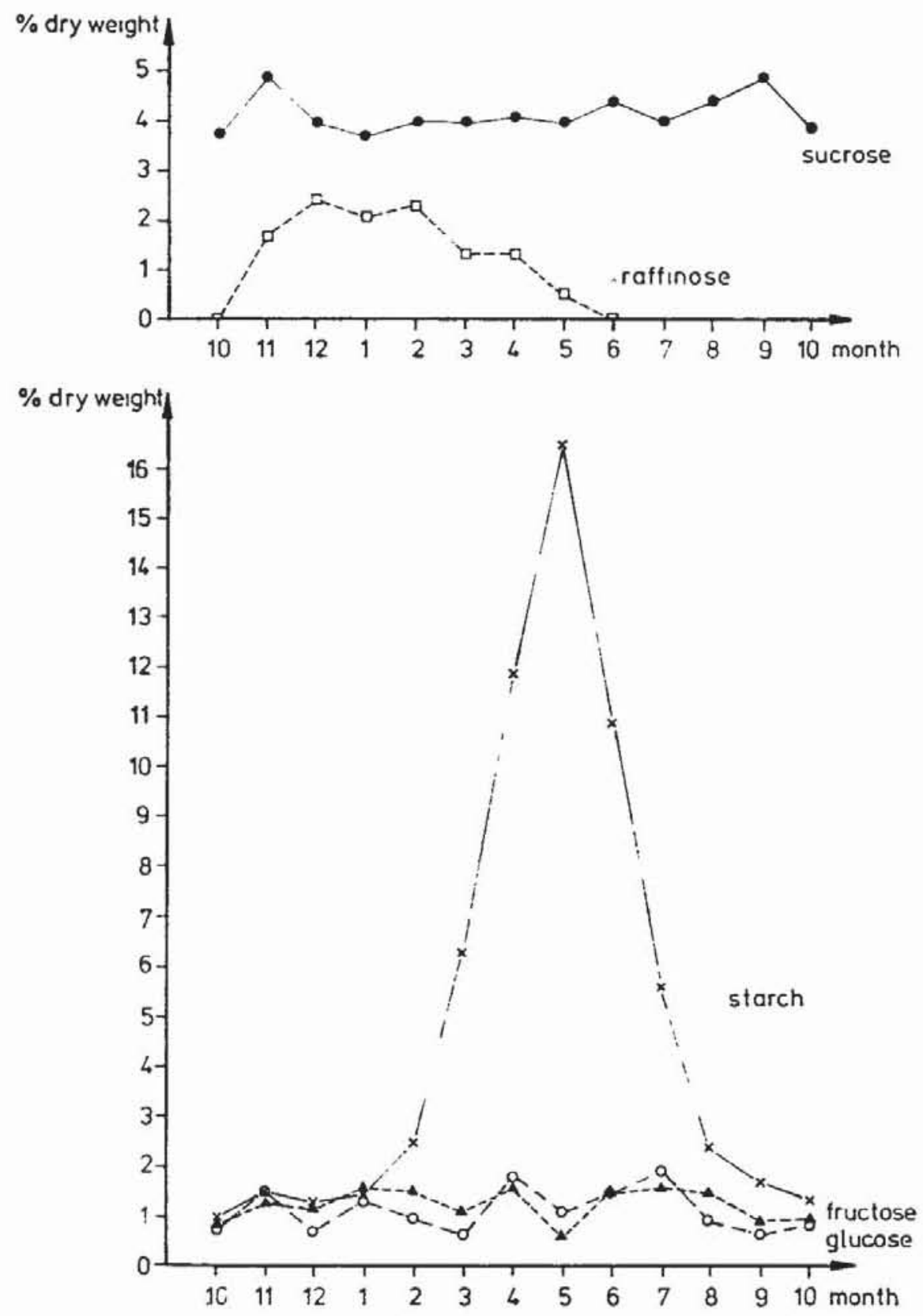

Fig. 1. Contents of sugars and starch (as percent of dry weight) in leaves (needles) of Taxus baccata during the course of a year measured at monthly intervals. 

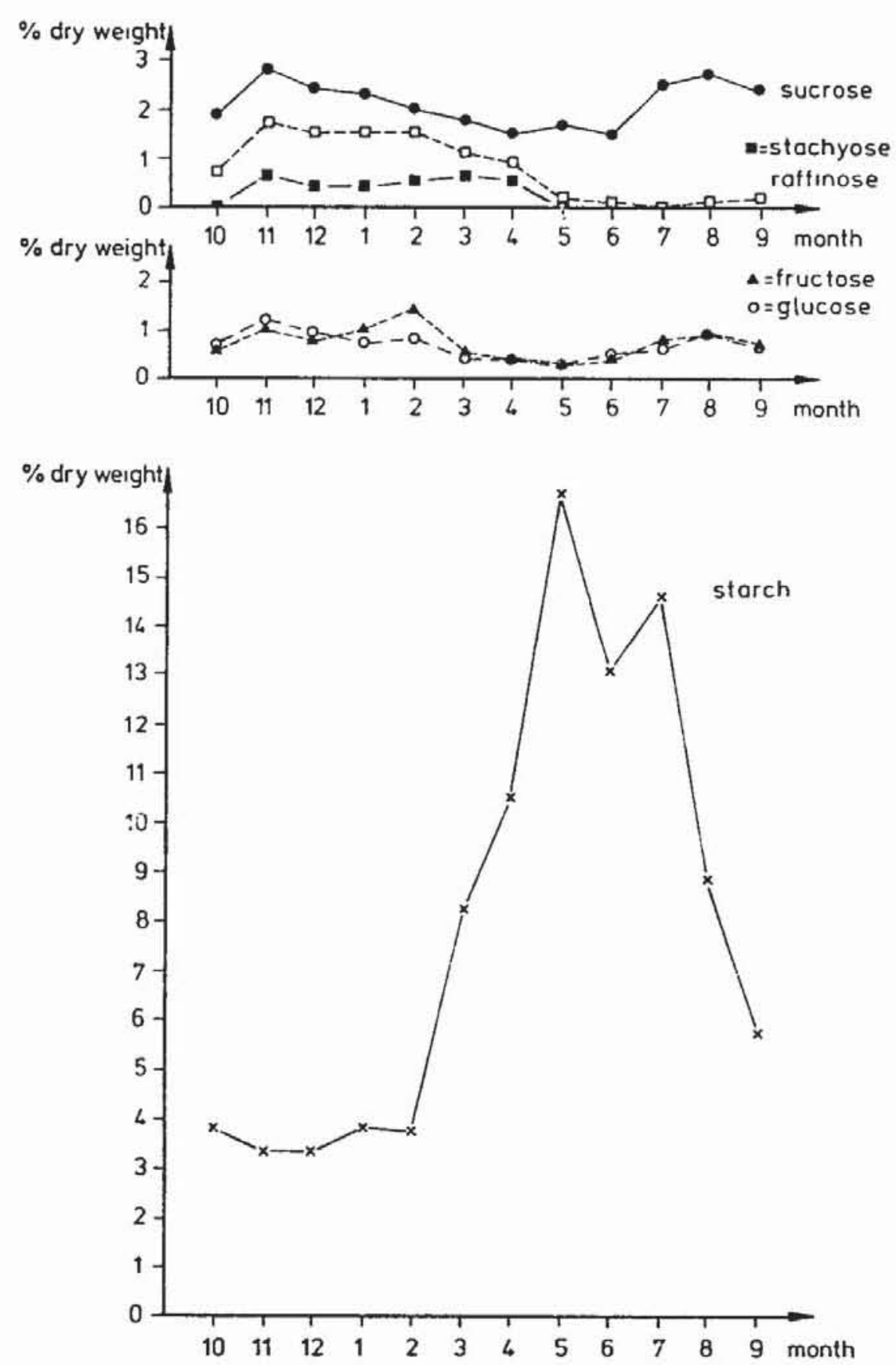

Fig. 2. Contents of sugars and starch (as percent of dry weight) in barks of Taxus baccata during the course of a year measured at monthly intervals.

\section{Seasonal trends of carbohydrate contents}

The results from leaves and barks of Taxus baccata are presented in Figs. 1 and 2 as a typical example of the carbohydrate variation throughout a year. For the 2 species, Juniperus and Thuja, the individual data were quoted by Distelbarth (1982); from these data the energy contents were calculated as shown in Figs. 5 and 6. In all the tissues investigated the well known accumulation of raffinose sugars during the winter months takes place; in Juniperus this accumulation is covered by raffinose only. In the leaves of Thuja raffinose is still found during the main growth period in the late spring. The sucrose content rises in some tissues during the cold season (leaves and barks of Juniperus, leaves of Thuja), but not in others (barks of Taxus 

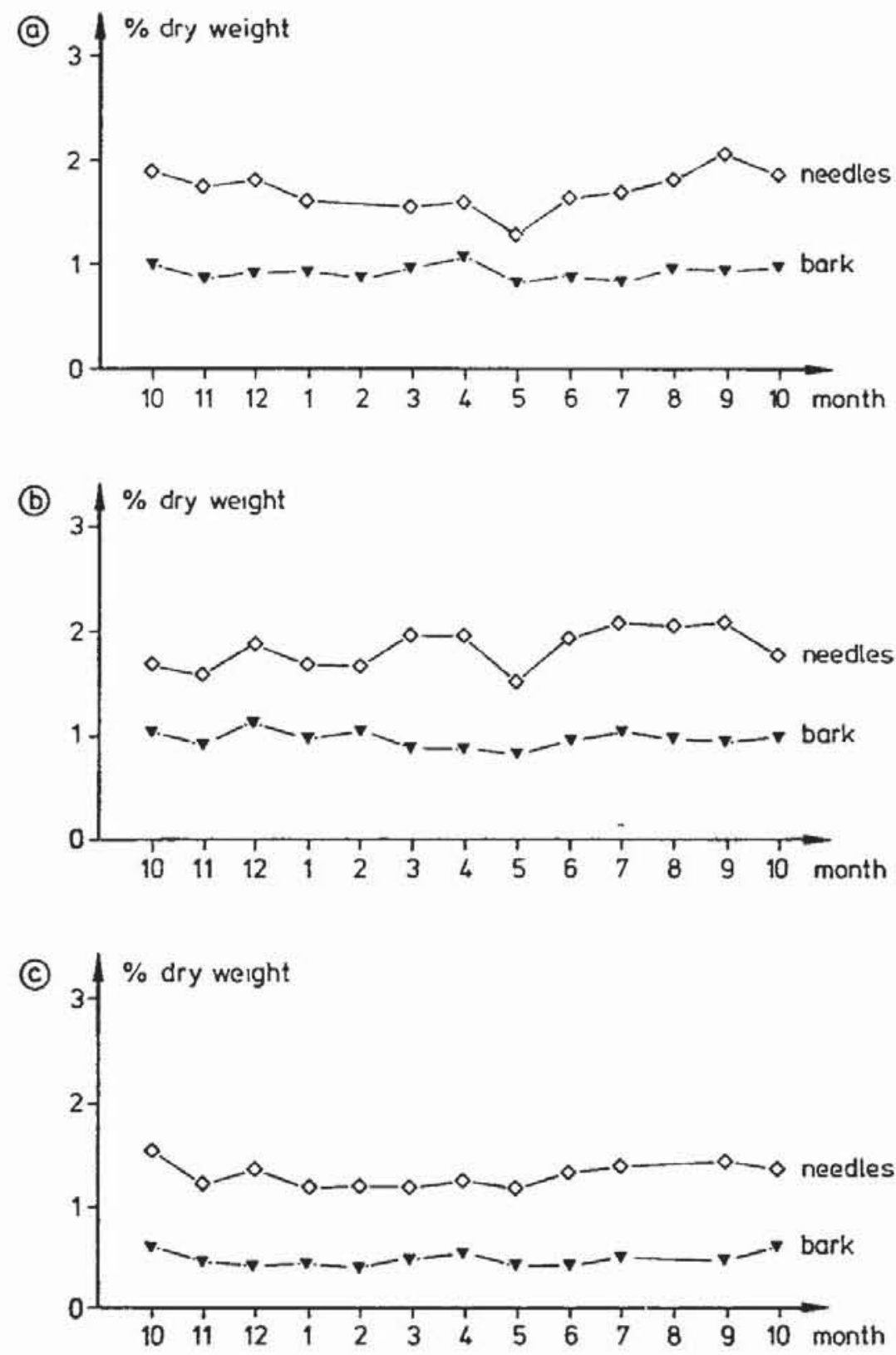

Fig. 3. Contents of total nitrogen (as percent of dry weight) in leaves and barks of Taxus baccata (a), Juniperus communis (b) and Thuja occidentalis (c) during the course of a year measured at monthly intervals.

and Thuja). In the needles of Taxus the content of sucrose is rather constant throughout the whole year. The starch content in Taxus rises very distinctly during the period of main growth activity from April to early summer. Also, in needles of Juniperus, the content of starch in the spring surmounts to $10 \%$ of the dry weight.

\section{Nitrogen content}

The total nitrogen content of both, leaf and bark material from Taxus, Juniperus and Thuja was determined to investigate whether $\mathrm{N}$-compounds are important energy storage substances. In the barks, the seasonal variations of the $\mathrm{N}$-content are very small (Fig. 3); in the needles, the highest amounts are found in late summer and in autumn while the lowest values are found in May. Only a portion of the $\mathrm{N}$-compounds 2* 
Table 2. Contents of carbonic acids as \% of dry weight in leaves (1 year old) of Picea abies during the course of a year measured at monthly intervals

\begin{tabular}{lllll}
\hline Month & quinic acid & shikimic acid & citric acid & malic acid \\
\hline 5 & 2.3 & 1.4 & 0.4 & 0.3 \\
6 & 2.2 & 1.7 & 0.4 & 0.2 \\
7 & 1.1 & 1.6 & 0.2 & 0.2 \\
8 & 1.7 & 4.0 & 0.6 & 0.1 \\
9 & 1.2 & 4.0 & 0.4 & 0.2 \\
10 & 0.7 & 3.4 & 0.4 & 0.2 \\
11 & 0.7 & 3.2 & 0.5 & 0.3 \\
12 & 0.7 & 3.2 & 0.7 & 0.7 \\
1 & 1.2 & 3.8 & 0.7 & 0.4 \\
2 & 1.1 & 3.9 & 0.8 & 0.5 \\
3 & 0.9 & 3.0 & 0.9 & 0.4 \\
4 & 1.1 & 3.0 & 0.5 & 0.4 \\
5 & 0.8 & 3.6 & 0.5 & 0.4 \\
\hline
\end{tabular}

can be regarded as storage substances. Approximately it is that portion, which is above the lowest content found. The total energy content contributed by this portion is small; $\mathrm{N}$-compounds do not therefore contribute significantly to the energy storage of the plants investigated (maximal value only about $0.5 \mathrm{~kJ} / \mathrm{g}$ ). Therefore, when the total energy of storage substances is calculated, the $\mathrm{N}$-compounds were not taken into account.

\section{Content of carbonic acids}

Some conifers accumulate rather high amounts of carbonic acids in their leaves (OECHSSLER 1968; DitTRICH \& KANDLER 1971); the energy content of these substances could be a significant proportion of the total energy of storage products. Therefore the seasonal trends of carbonic acid contents of Picea needles were measured and the findings supplemented by four checks during different seasons on leaves of Taxus. The variations of the carbonic acid content found in the leaves of Picea are similar to OECHSSLER's observations on one year old needles. Quinic and shikimic acids share more than three quarters of the total organic acid content (Table 2). Malic and citric acids also where quantified; succinic and fumaric acids contributed always less than $0.2 \%$ of total dry weight. The energy content of quinic and shikimic acids during the course of a year varies between 0.5 and $1 \mathrm{~kJ} / \mathrm{g}$ dry weight; values higher than $0.75 \mathrm{~kJ}$ are reached in January/February and in August/September. These energy values and their fluctuations are low compared with those of the other storage substances. In the needles of Taxus, the total amount of carbonic acids in all samples examined was between 1 and $2 \%$ of total dry weight. The same acids as in Picea were also quantified. Quinic and shikimic acids together share $0.7-1,3 \%$ of total dry weight. The energy content of these carbonic acids is therefore insignificant.

\section{Seasonal trends of storage substances and their energy contents}

The energy contents of the storage substances of leaves and barks of Taxus, Juniperus, Thuja, Picea and Sequoiadendron are shown in Figs. 4-8. In addition the energy contents of reserve substances in the wood of branches from Taxus and Juniperus are stated. The amount of soluble sug urs and therefore its energy content in all 
Taxus
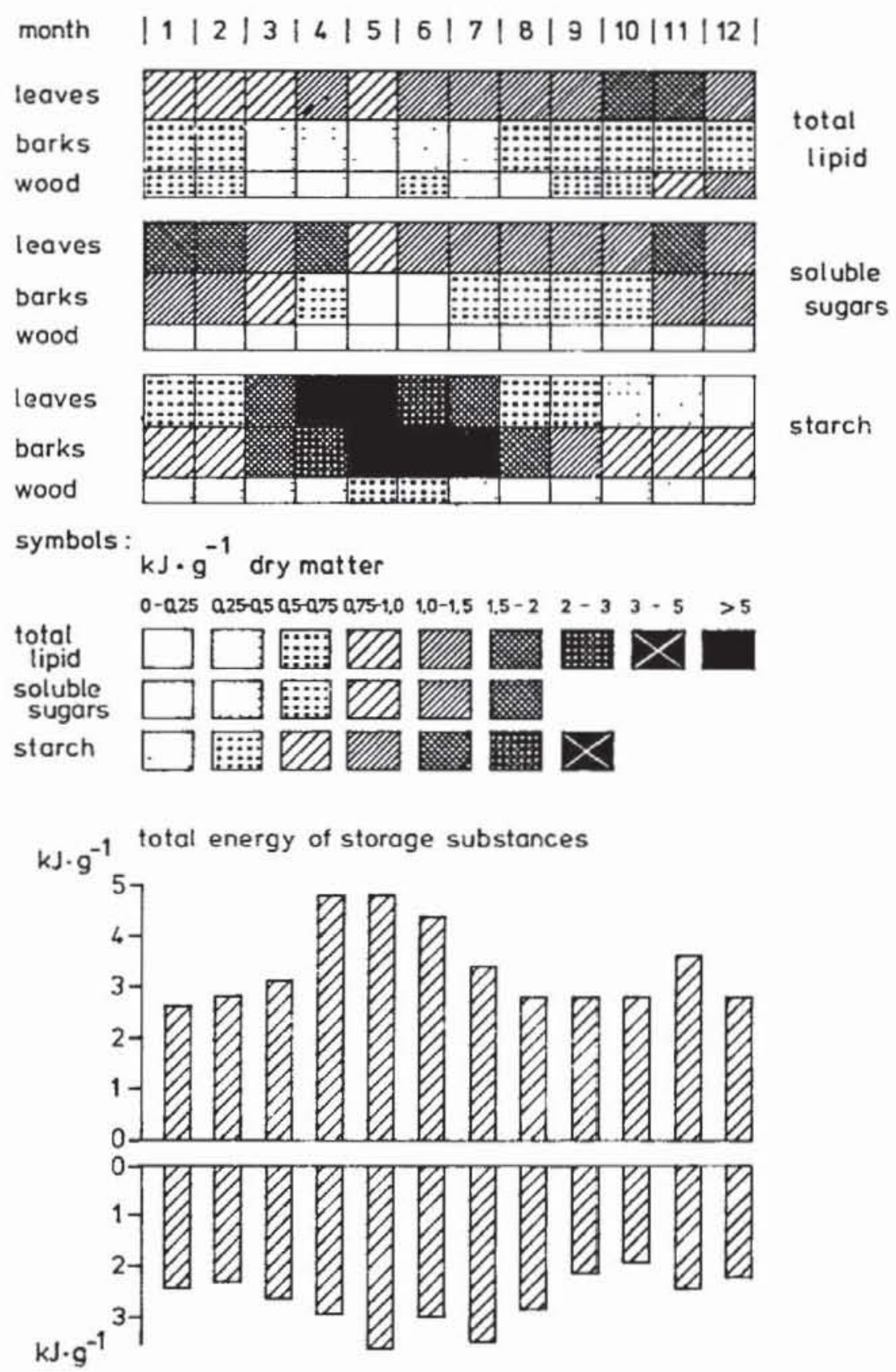

Fig. 4. Calculated energy contents of storage substances (total lipids, soluble sugars, starch) of leaves, barks and wood of Taxus baccata and total energy of storage substances calculated for leaves (upper diagram) and barks (lower diagram). All data in $\mathrm{kJ} / \mathrm{g}$ dry matter.

species show the lowest value during the late spring and during the summer. In barks, the minimum sugar content is less than in the leaves. In the needles of Thuja the depletion of sugars starts particularly early. The highest sugar content in the barks is always found during the cold season; the s?me ist true for the leaves with the exception of Sequoiadendron, where the highest level is reached in the spring. The sugar content, and therefore its energy value, in the wood of Taxus and Juniperus is very low and varies little throughout the year.

The starch contents show the highest levels in the spring, both before and during the main growth period; high amounts are found in some species up to the summer. 
Juniperus

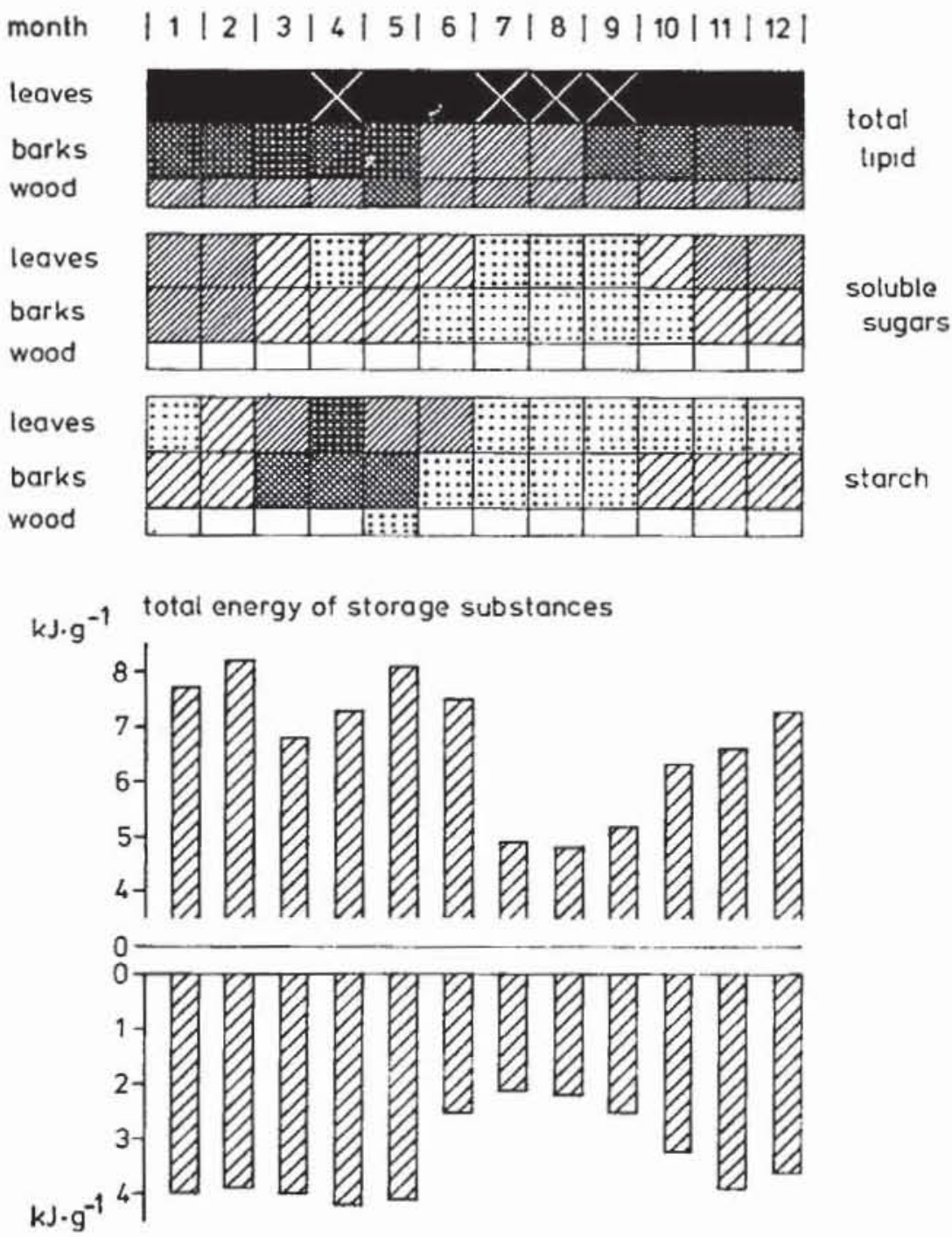

Fig. 5. Calculated energy contents of storage substances of leaves, barks and wood of Juniperus communis and total energy of storage substances for leaves and barks, calculated as in Fig. 4. Symbols as in Fig. 4.

In Taxus and Juniperus, the starch content increases in early spring, while in Sequoiadendron rather late in the spring. In wood, starch variations are small, but a relatively high content is seen during the spring. The lowest starch content in all tissues is found during the late autumn and in the winter; there is only one exception, the barks of Juniperus.

The amount of total lipids in the leaves is in most cases highest during the late autumn. In some species (Taxus, Sequoiadendron) it declines dramatically during the winter. In other species, as in Thuja, there is only a modest decrease. In the barks of all species investigated, the lipid content shows a maximum during the winter months; in barks of Picea and Juniperus very high amounts are found up to the spring. The needles of Juniperus have a very high lipid content during the vegetation period. In the leaves the lowest amounts of lipids are found during the late winter and in the spring. However, in the barks, low lipid levels occur in most cases during the spring and summer months and in barks of Picea in the autumn. The wood of 


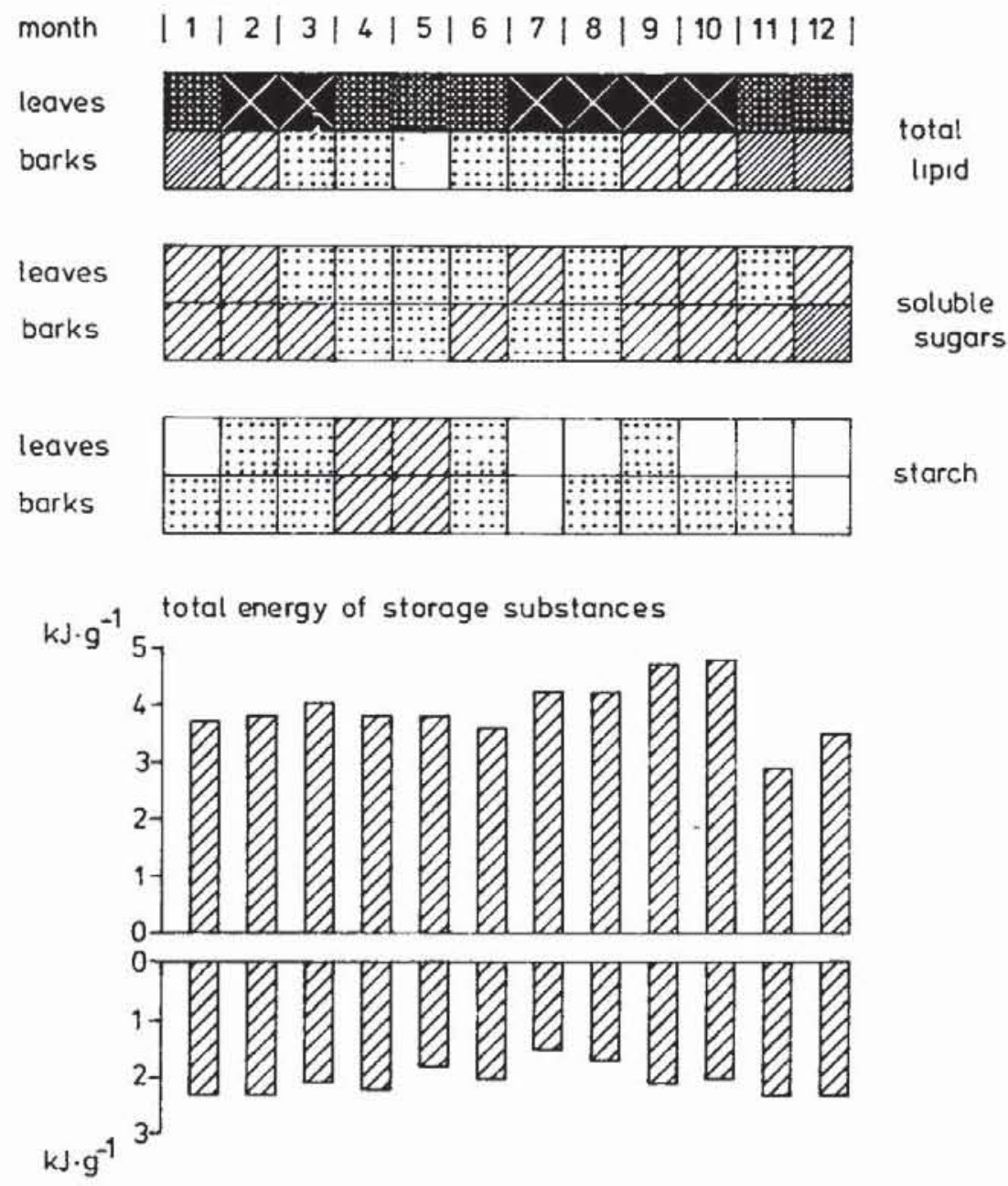

Fig. 6. Calculated energy contents of storage substances of leaves and barks of Thuja occidentalis and total energy of storage substances for leaves and barks. Symbols as in Fig. 4.

Taxus contains the highest lipid contents in the early winter, that of Juniperus during the vegetation period. In Juniperus wood the seasonal variations are rather small.

Comparing the species we see that in Taxus starch shares the biggest part of storage-energy but in the other four species the greatest proportion is covered by the lipids. The highest percentage of the energy storing substances are reached by the lipids in Juniperus.

By counting up the energy content of the main storage products (lipids, sugars, starch) we estimated a total energy content (per g of dry weight) (Figs. 4-8).

In the.leaves, the total energy content of reserve substances has values ranging from $3-5 \mathrm{~kJ} / \mathrm{g}$; only the needles of Junigerus show distinctly higher rates (more than $8 \mathrm{~kJ} / \mathrm{g}$ ). The deviations during the course of a year average $2 \mathrm{~kJ} / \mathrm{g}$; however in Juniperus they reach more than $3 \mathrm{~kJ} / \mathrm{g}$. In the leaves, the highest energy content of storage substances is found in most species during the winter. However, in Taxus the highest levels occur during the vegetation period. The leaves of Juniperus show a biphasic accumulation pattern, with high energy contents peaking during the vegetation period as well as during the winter. In Thuja the seasonal variations are rather low and the highest energy values are reached in the autumn. In all species the total energy of the storage products in the needles is lowest when the growth period has 
Picea

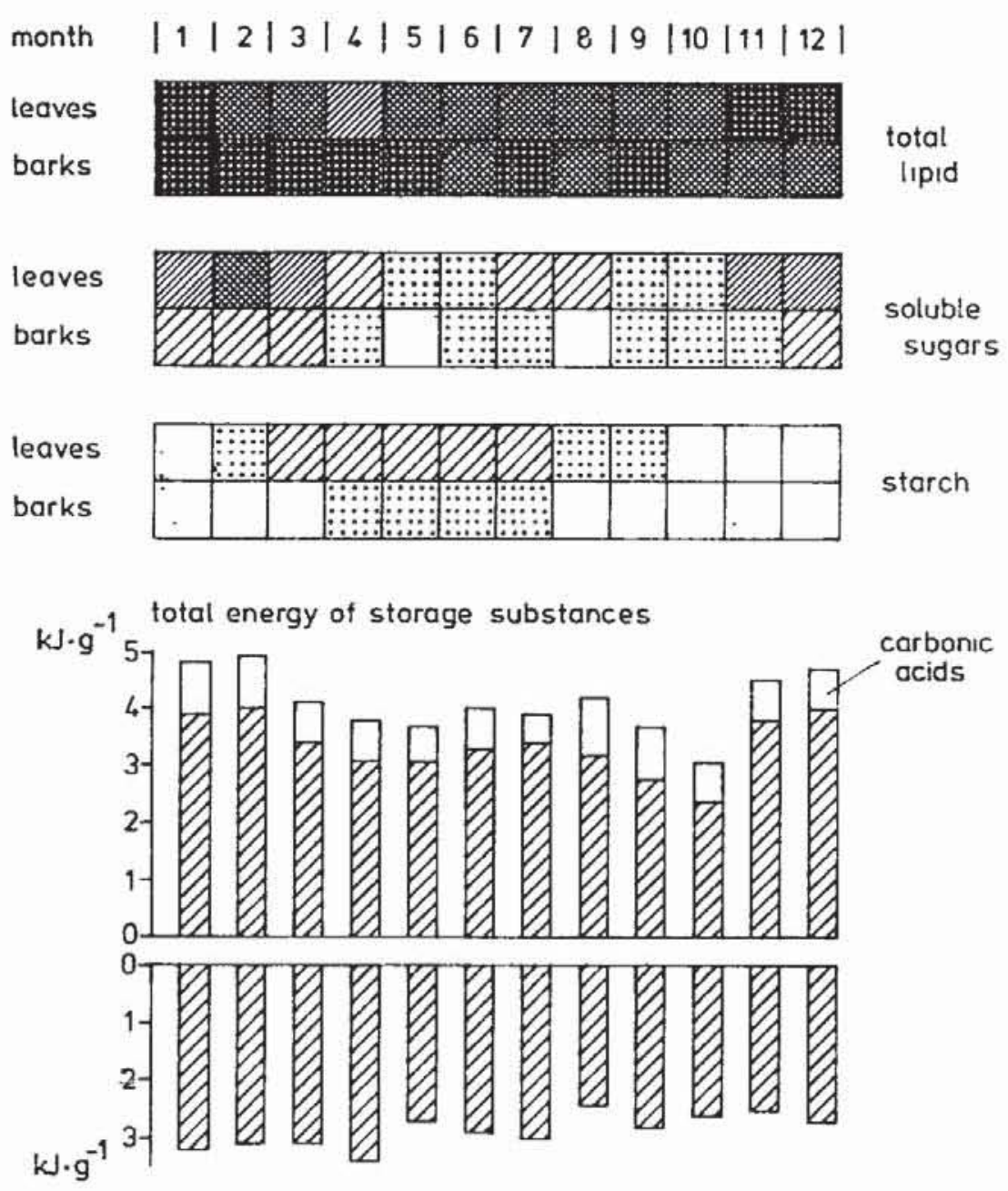

Fig. 7. Calculated energy contents of storage substances of leaves and barks of Picea abies and total energy of storage substances for leaves and barks. Symbols as in Fig. 4.

finished and in some cases the low values last to October. But in no case is the energy minimum very distinct.

In the barks, the energy contents are generally lower and range from $2-4 \mathrm{~kJ} / \mathrm{g}$. The seasonal variations are distinct only in the barks of Taxus and Juniperus; the periodicity is similar to that found in the leaves.

In the wood of Taxus the energy value of the storage substances is in the range $0.5-1,9 \mathrm{~kJ} / \mathrm{g}$ with values higher than $1 \mathrm{~kJ}$ being reached during the winter months and again in June. In the wood of Juniperus the energy content fluctuates between 1.6 and $2 \mathrm{~kJ} / \mathrm{g}$ with the variations throughout the year being rather small.

From a comparison of the species investigated several regularities and similarities of the energy storage behavior may be recognized and a general storage behavior of evergreen gymnosperms growing under mild climatic conditions in Central Europe can be deduced (Fig. 9). From this pattern, only minor deviations in one or the other species are observed. Fig. 9 characterizes the rela ${ }^{4}$ ive fluctuations of the different storage substances. For wood, the generalization is lased solely upon the data from Taxus and Juniperus, and therefore is less exact and only three different symbols are used. Remarkably, the highest starch contents are generally found in the late spring and not during the summer or early autumn. 


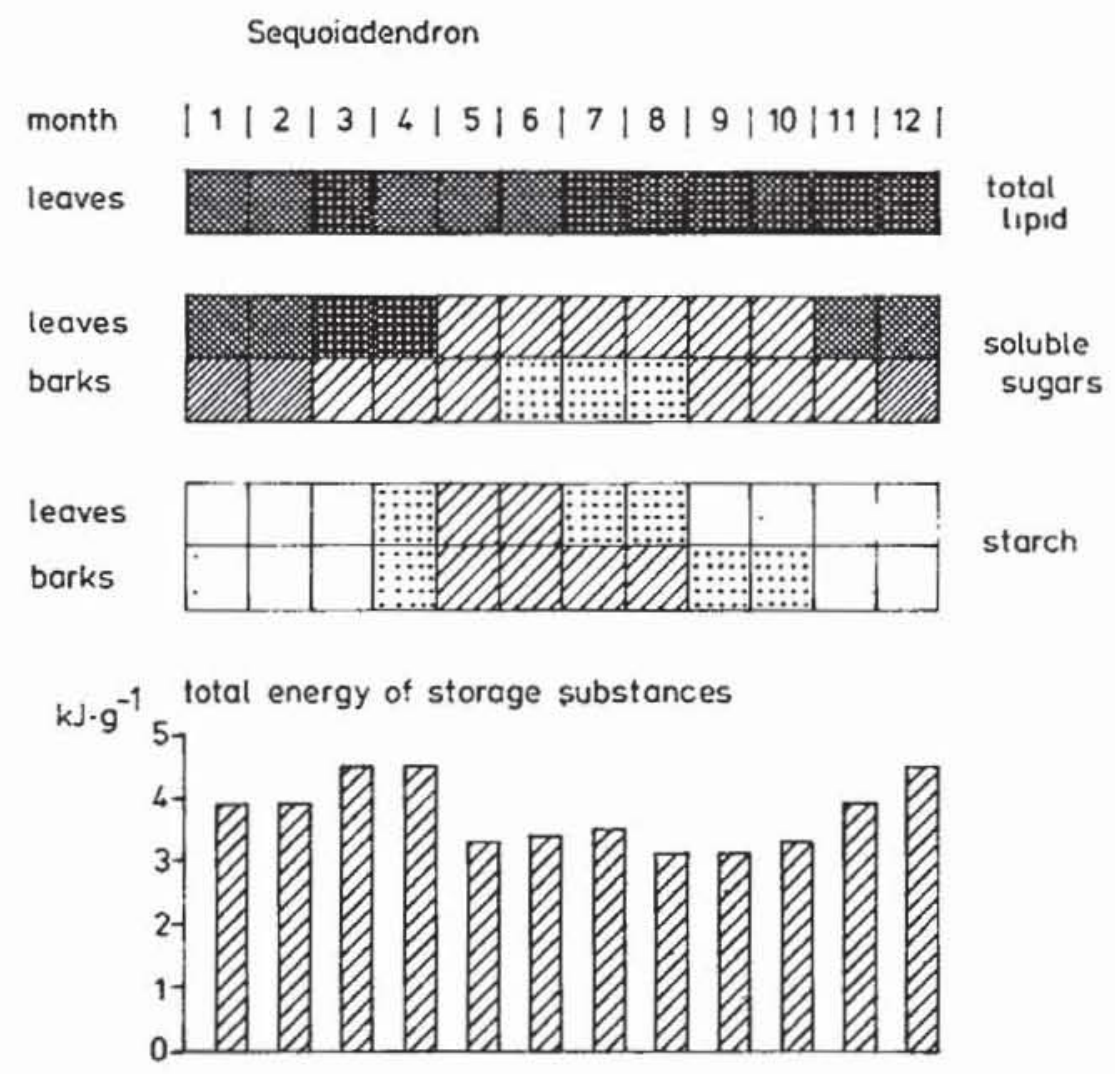

Fig. 8. Calculated energy contents of storage substances of leaves and barks of Sequoiadendron giganteum and total energy of storage substances for leaves. Symbols as in Fig. 4.

\section{Discussion}

Our measurements of storage substances are in good agreement with those of other investigations dealing with similar climatic conditions (Picea: Diamantoglou 1974; Senser et al. 1975; Picea and Thuja: Senser et al. 1971; Taxus: Höllwarth 1977). As described by Glerum \& Balatinecz (1980) from Pinus banksiana carbohydrates and lipids are the main storage products in gymnosperms. In agreement with GLERUM \& BALATINECZ our investigation showed that the accumulation of lipids during the autumn is not restricted to the wood (comp. also ZIEGLER 1960). N-compounds are occasionally thought to be significant energetic storage materials. However, GLERUM \& BALATINECZ (1980) showed that they are insignificant. The same can be concluded from our data. From an energetic point of view, the variations in the amounts of $\mathrm{N}$-compounds are unimportant. In the leaves of three of the species investigated (Taxus, Juniperus, and Thuja) we find the lowest N-content in the spring. Probably Ncompounds shift from the examined one year old needles into the new shoots and their needles_. Obviously, the old needles are serving as an N-reservoir. Several other investigators also found that one year or older needles are main reservoirs of different storage products of conifers (Kimura 1969; WebB 1975; GLerum \& Balatinecz 1980; LUNDERSTÄDT 1980). In Populus, a deciduous tree, the N-content in the bark of twigs declines to the lowest value in the spring (HöLLwarth 1976). Contrary to this behaviour, in the bark of gymnosperms there is no depletion of $\mathrm{N}$-compounds during the spring.

We have compared our findings with those of Krmura (1969), Litrue (1970) and PoMEroy et al. (1970) on conifers growing under more continental (alpine or boreal) climatic conditions. The results of these authors are similar to ours if one takes into 


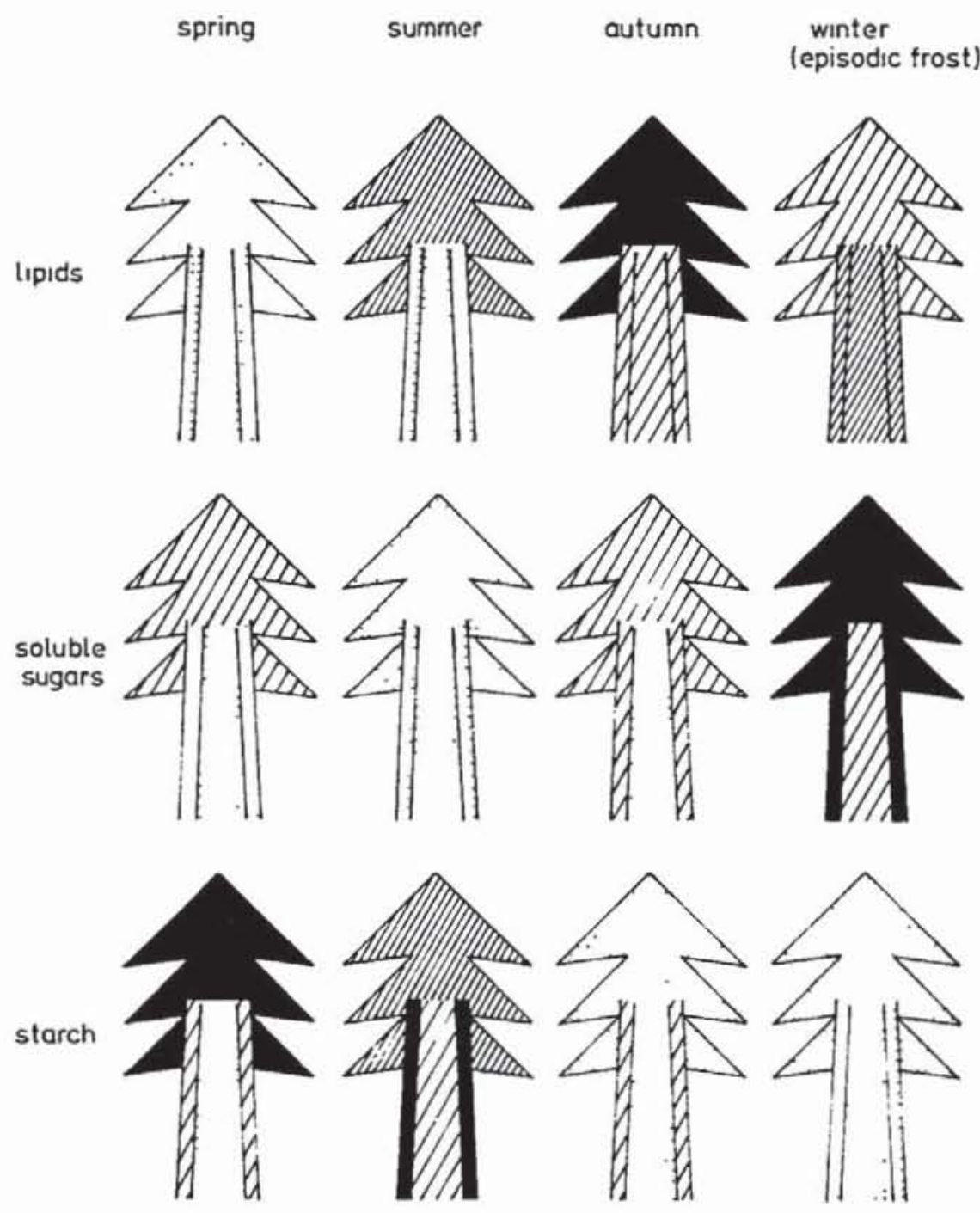

Fig. 9. Variations in the deposition of total lipids, starch and soluble sugars by evergreen gymnosperms under mild climatic conditions in Central Europe throughout a year. Maximal accumulation is indicated in black, large amounts by narrow cross-hatching, medium-sized amounts by distant crosshatching and small amounts by stippling. For wood, only 3 different symbols are used.

consideration the shorter vegetation periods causing a delayed seasonal growth. In all cases the highest starch contents were found before and at the beginning of growth in the spring (in Abies veitchii in the alpine zone by Krmora 1969, in Pinus resinosa in Canada by Pomeroy et al. 1970, and in Abies balsamea in Canada by LITTLE 1970). The sugar contents show the same seasonal trends in all cases, but were much higher in Abies veitchii and Abies balsamea than in our species. The lipid contents have only small variations in Abies balsamea, however, the fluctuations are somewhat greater in Abies veitchii and in this species the highest amounts are found after cessation of seasonal growth, as is true for our species.

Our results should also be compared with thuse of Diamantoglou \& MeletiouChristou (1981) and Diamantoglou \& Kull (1982), who reported on evergreen mediterranean species. In these investigations only Pinus halepensis as a conifer was analysed. In this species the energy contents of the storage products in the barks and needles were definitely lower than in the Central European gymnosperms. In the broad-leaved sclerophyllous mediterranean species the energy contents are similar 
to those of our gymnosperms, but there is a conspicuous difference in the seasonal trends of sugar accumulation between mediterranean and Central European species. On the other hand, the seasonal trends of starch contents are relatively similar when taking into consideration the earlier growth initiation in the mediterranean region. During the winter we find low starch contents in Central European species, but rather high amounts in the mediterranean species. The seasonal trends in lipid accumulation of barks in Central European gymnosperms are similar to those of the mediterranean species. However, in the leaves, the highest values in Central European species are reached in the autumn, but in the mediterranean species during the winter (comp. also DAvid et al. 1959). These patterns of lipid accumulation do not coincide with the data of Butrose \& Hale (1971) from Vitis; they had found a temperaturedependent storage of lipids and starch. However, according to HAwKER (1982) the temperature may not be critical for lipid accumulation. The same can be concluded from the findings of LitTLE (1970). Also, the diminution of the starch content in the Central European species during the summer seems not to be primarily caused by the temperature, as was concluded by SAUTER (1967) from his results of temperatureexperiments.

In the leaves of the Central European gymnosperms the lipids are partly metabolized during the winter months. The same is true for the alpine chamaephyte Loiseleuria growing under much more severe climatic conditions (TSCHAGER et al. 1982). In the mediterranean as in the Central European species the lowest lipid contents are found in the beginning of the growth period.

All these data together confirm the earlier suspicions (TschAGER et al. 1982) on the conditions and functions of the storage of the different reserve substances. When stress-conditions are prevalent, soluble sugars are accumulated. In periods without a prolonged stress and when a rather quick mobilization of energy substances is necessary, starch is synthesized. In times of considerable net production when growth has finished and transport therefore is reduced and there is no stress, we find an accumulation of lipids.

In all the gymnosperms which we have investigated, except Taxus, the largest part of the total energy is stored throughout the year in lipids. The same was found for the mediterranean sclerophylls (Diamantoglou \& Kull 1982). In Taxus, the main storage component is carbohydrates. In Thuja and in Picea the fluctuations of the total energy contents are determined mainly by the variations in the amounts of lipids, but for Juniperus - in spite of its high lipid contents - this is not true. In Taxus and Juniperus, lipids seem to be minor storage substances compared to carbohydrates, as was concluded by Litrie (1970) for Abies. However, the findings with Thuja and Sequoiadendron suggest that this is not true for the conifers in general. The energy content of the wood based on the dry weight is low in the two species investigated. In the harvested branches of Taxus the relation of the dry weight of leaves: bark: wood is 12:4:9. The great branches and the stem are not included in this ratio, so for the whole tree, the share of the wood must be considerably higher, therefore its energy content is of greater importance than may be seen from the values at first sight.

Only in Juniperus the total energy of the storago substances has an extremely low value at the end of the growth period. In mediterranean evergreen sclerophylls such a minimum is very distinct because it coincides with the summer drought period (Diamaxtoglou \& Kull 1982). Obviously, the high photosynthetic rate in Central Europe during the summer months causes an immediate supply of reserve substances. From November to February the energy content of the leaves rises or remains con. stant except in Taxus and Sequoiadendron. In the barks during the same period the 
energy value remains fairly constant. Evidently, under the mild climatic conditions of the Central European habitat there is a net photosynthetic production during the winter. Also, the water-balance of the leaves is not stressed in our plants in the winter, as may be seen from a comparison of the measured water-contents with the data of LARCHER (1972). A net photosynthetic production during winter in gymnosperms under mild climatic conditions was also shown by GÄUMANN (1927), HeLms (1965); Pollard \& Wareing (1968); Fry \& Phillips (1977); Bradbury \& Malcola (1978) (further literature Kozlowski \& Keller 1966 and in Peschl 1982). Under more continental climatic conditions there is no net assimilation in winter-time (SCHULzE et al. 1977, further literature compare Peschl 1982). The same is true for alpine conditions (PISEK \& Winkler 1958; Krmura 1969, and others). Consecutive frosts never occurred during our investigation, therefore, no cessation of $\mathrm{CO}_{2}$-uptake as a result of an increased stomata resistance (BoURDEAU 1959; ÖQUIST et al. 1980; LARCHER \& BAUER 1981) took place. Experiments by IRGA-method with Taxus established normal photosynthetic rates in January after less than $1 \mathrm{~h}$ adaptation to room-temperature. The frost-hardiness of such Taxus twigs was high and comparable to that reported by MELzack \& WATTS (1982).

The amplitude in seasonal fluctuations of the total storage energy, which we found to be high in' Juniperus, medium in Taxus and low in the other three species, may be caused by the different growth characteristics of the different species. The material of Juniperus was harvested from a shrub, that of Taxus from a tree on only small stems; this scrubby form of growth is often found in Taxus. The twigs from the other species were taken from trees with rather thick stems and big branches. The material investigated always was taken from twigs younger than 7 years. In Picea, Thuja, and Sequoiadendron the large branches and the stem share a greater proportion of the total dry weight of the plant than in the other 2 species and therefore may contain a greater proportion of the storage substances. We should also consider, that the C-balance of shrubs, shrubby trees and trees each may be somewhat different from one another (Schulze 1982).

\section{Acknowledgements}

The authors gratefully acknowledge the help of Mrs. Ursula TAyebi, Mr. Peter NeUHäUsLer and Mr. Gerhard Haussmans in the experimental investigations and the correction of the English by Mr. Richand Cyr, University of California, Irvine.

\section{References}

Beloserski, A. N., \& Proskurjakow, N. T. (1956): Praktikum der Biochemie der Pflanzen. Dtseh. Verlag d. Wiss., Berlin.

BLIGH, E. G., \& DYer, W. J. (1959): A rapid method of total lipid extraction and purification Canad. J. Biochem. Physiol. 37: 911-917.

Bourdeau, P. F. (1959): Seasonal variations of the photosynthetic efficiency of evergreen conifers. Ecology 40: 63-67.

Bradbury, I. K., \& Malcolm, P. C. (1978): Dry matter aecumulation by Picea sitchensis seedlings during winter. Canad. J. Forest Res. 8: 207-213.

Buttrose, M. S., \& HALE, C. R. (1971): Effects of temperature on accumulation of starch on lipid in chloroplasts of grapevine. Planta 101: 166-170.

David, R., Larraz, G., Bernard, C., \& Demounem, R., (1959): Evolution de l'amidon et des composés soudanophiles dans les pseudophylles de Pinus caribea Mor. et de Pinus pinaster Sot. C. R. Acad. Sci. 249: 2820-2822.

Diamantoglou, S. (1974): Uber das physiologische Verhalten von Cycliten in vegetativen Teilen höherer Pflanzen. Biochem. Physiol. Pflanzen 166: 511-523. 
— \& KuLL, U. (1982): Die Jahresperiodik der Fettspeicherung und ihre Beziehungen zum Kohlenhydrathaushalt bei immergrünen mediterranen Holzpflanzen. Acta Oecol./Oecol. plant. 3: $231-248$.

- \& Meletiou-Christor, M. S. (1981): Changes of storage lipids, fatty acids and carbohydrate in vegetative parts of mediterranean evergreen sclerophylls during one year. In: Margaris, N. S., \& MooneY, H. A. (eds.): Components of productivity of mediterranean-climate regions; basic and applied aspects; pp. 121-127. Junk, The Hague.

Distelbarth, H. (1982): Die Schleimpolysaceharide von Taxus baccata und Thuja occidentalis. 192 S. Diss. Univ. Stuttgart.

Dittrich, P., \& Kandler, O. (1971): Einfluß der Jahreszeit auf Bildung und Umsatz von Phenolkörpern in der Fichte (Picea abies (L.) KARST.). Ber. dtsch. Bot. Ges. 84: 465-472.

Fry, D. J., \& Phillips, I. D. J. (1977): Photosynthesis of conifers in relation to annual growth cycles and dry matter production. Physiol. plant. 40: 300-306.

Gĩumaxs, E. (1927): Der jahreszeitliche Verlauf des Kohlenhydratgehaltes im Tannen- und Fichtenstamm. Ber. dtsch. Bot. Ges. 45: $591-597$.

Glenum, C., \& Balatinecz, J. J. (1980): Formation and distribution of food reserves during autumn and their subsequent utilization in jack pine. Canad. J. Bot. 58: 40-54.

Hawker, J. S. (1982): Effect of temperature on lipid, starch, and enzymes of starch metabolism in grape, tomato, and broad bean leaves. Phytochemistry 21: $33-36$.

Heitefuss, R. (1957): Erfahrungen zur quantitativen papierchromatographischen Bestimmung organischer Säuren. Angew. Bot. 31: 61-62.

Helms, J. A. (1965): Diurnal and seasonal patterns of net assimilation in Douglas-fir, Pseudotsuga menziesii (Mrrb.) Franco, as influenced by environment. Ecology 46: 698-708.

Hōllwarth, M. (1976): Der Stickstoffhaushalt von Pappelrinden und seine Beziehungen zur Temperatur. Z. Pflanzeriphysiol, 80: 215-224.

- (1977): Zum Verhalten einiger Kohlenhydrate aus Nadeln von Taxus baccata L. an städtischen Standorten unterschiedlicher Immissionsbelastung. Angew. Bot. 51: 277-285.

Jeremias, K. (1958): Utber den Jahresgang einiger Zucker in den Blättern von Hedera helix. Planta 52: 195-205.

- (1969a): Speicherungsphysiologische Untersuchungen bei Picea abies und Sequoiadendron giganteum. Mitt. Ver. Forstl. Standortskunde. Fortpflanzenzüchtung 19: 58-66.

- (1969 b): Zur winterlichen Zuckeranhäufung in vegetativen Pflanzenteilen. Ber. dtsch. Bot. Ges. 82: 87-97.

Krmura, M. (1969): Ecological and physiological studies on the vegetation of Mt. Shimagare. VIII. Analysis of production processes of young Abies stand based on the carbohydrate economy. Bot. Mag. Tokyo 82: 6-19.

Kjeldaht, J. (1883): Uber die Stickstoffbestimmung. Z. Analyt. Chem. 22: 366-370.

Kozlowski, TH. T., \& Keller, TH. (1966): Food relations of woody plants. Bot. Rev. 32: 293382.

Kuxx, U. (1968): Die Jahresperiodik einiger nichtflüchtiger Carbonsäuren in Sempervivum tectorum L. Planta 79: 299-311.

LARChER, W. (1972): Der Wasserhaushalt immergrüner Pflanzen im Winter. Ber. dtsch. Bot. Ges. 85: $315-327$.

- \& Bautr, H. (1981): Ecological significance of resistance to low temperature. In: Encycl. Plant Physiol., N. S., 12A: Physiological Plant Ecology I, eds. O. L. Lange, P. S. Nobex, C. B. OSMOND, H. TIEGLER: $403-437$.

Litrue, C. M. A. (1970): Seasonal changes in carbohydrate and moisture content in needles of balsam fir (Abies balsamea). Canad. J. Bot. 48: 2021-2028.

LoEwUs, F. (1952): Improvement in anthrone method for determination of carbohydrates. Analyt. Chem. 24: 219.

Lunderstädr, J. (1980): Zur ökophysiologischen Bedeutung von Phenolen und Proteinen in Nadeln der Fichte (Picea abies Karst). Z. Pflanzenernähr. Bodenkunde 143: 412-421.

McCready, R. M., Guggolz, J., Silviera, V., \& Owens, M. S. (1950): Determination of starch and amylose in vegetables. Analyt. Chem. 22: 1156-1158.

Melzack, R. N., \& Watrs, D. (1982): Cold hardiness in the yew (Taxus baccata L.) in Britain. J. Biogeography 9: 231-241. 
Naglschimd, F., Kull, U., \& Jeremias, K. (1982): Physiologische Untersuchungen über Blattschleime. I. Untersuchungen an Verbascum densiflorum. Biochem. Physiol. Pflanzen 177: $671-685$.

Nierhaus, D., \& KnNzeL, H. (1971): Vergleichende Untersuchungen über die organischen Säuren in Blättern höherer Pflanzen. Z. Pflanzenphysiol. 64: 107-123.

Oechssler, G. (1968): Jahreszeitliche Schwankungen des Gehalts an organischen Säuren in den Nadeln von Pseudotsuga menziesii (Mrrb.) Franco, Picea abies (L.) H. Karsten und Larix decidua MrLL. Z. Pflanzenphysiol. 59: 213-225.

Oquist. G., Brunes, L., Hällgren, J. E., Gezelids, K., Hallen, M., \& Malmberg, G. (1980): Effects of artificial frost, photosynthetic electron transport and RuBP carboxylase activity in seedlings of Pinus silvestris. Physiol. plant 48: 526-531.

Peschl, A. (1982): Reaktion des $\mathrm{CO}_{2}-$ und Wasserdampfgaswechsels abgehärteter Pflanzen von von Picea abies, Pseudotsuga menziesii and Abies grandies bei Frosttrocknis. Flora 172: 427 447.

Pisek, A., \& Winkler, E. (1958): Assimilationsvermögen und Respiration der Fichte (Picea excelsa LINK) in verschiedener Höhenlage und der Zirbe (Pinus cembra L.) an der alpinen Waldgrenze. Planta 51: 518-543.

Pollakd, D. F. W., \& Wareing, P. F. (1968): Rates of dry matter production in forest tree seedlings. Ann. Bot. 32: 573-591.

Pomeroy, M. K., Siminovitch, D., \& Wightman, F. (1970): Seasonal biochemical changes in the living bark and needles of red pine (Pinus resinosa) in relation to adaptation to freezing. Canad. J. Bot. 48: 953-967.

SAUTER, J. J. (1967): Der Einfluß verschiedener Temperaturen auf die Reservestärke in parenchymatischen Geweben von Baumsproßachsen. Z. Pflanzenphysiol. 56: 340-352.

Schulze, E.-D. (1982): Plant life forms and their carbon, water and nutrient relations. In: Encyclop. Plant Physiol., N. S., 12B, Physiological Plant Ecology II, eds. O. L. LANGE, P. S. NoBer, C. B. OSMOND, H. ZIEGLER: 615-676.

- Fuchs, M., \& FUCHS, M. I. (1977): Spatial distribution of photosynthetic capacity and performance in a mountain spruce forest of Northern Germany. III. The significance of the evergreen habit. Oecologia 30: 239-248.

Senser, M., Dittrich, P., Kandler, O., Thanbichler, A., \& Kuhn, B. (1971): Isotopenstudien über den Einfluß der Jahreszeit auf den Oligosaccharidumsatz bei Coniferen. Ber. dtsch. Bot. Ges. 84: $445-455$.

- Sсно̆тz, F., \& Веск, E. (1975): Seasonal changes in structure and function of spruce chloroplasts. Planta 126: $1-10$.

Tschager, A., Hitscher, M., Franz, S., Kull, U., \& Larcher, W. (1982): Jahreszeitliche Dynamik der Fettspeicherung von Loiseleuria procumbens und anderen Ericaceen der alpinen Zwergstrauchheide. Acta Oecol./Oecol. plant. 3: 119-134.

Webs, W. L. (1975): Dynamies of photoassimilated carbon in Douglas fir seedlings. Plant Physiol. 56: $455-459$.

ZIEGLER, H. (1960): Storage, mobilization and distribution of reserve material in trees. In: M. M. Zimmermann (ed.): The formation of wood in forest trees. Academic Press, London: 303-320.

Received May 2, 1983

Authors' address: Dr. Heidnun Distelbarth; Prof. Dr. U. Kun, Biologisches Institut der Universität Stuttgart, Ulmer StraBe 227, D - 7000 Stuttgart 60. 